\title{
Aridland constructed treatment wetlands II: Plant mediation of surface hydrology
}

enhances nitrogen removal.

Authors: Christopher A. Sanchez ${ }^{1}$, Daniel L. Childers ${ }^{1,4}$, Laura Turnbull ${ }^{2}$, Robert F. Upham ${ }^{3}$, and Nicholas Weller ${ }^{1}$

$7 \quad{ }^{1}$ School of Sustainability, Arizona State University, Tempe AZ USA

$8 \quad{ }^{2}$ Department of Geography, Durham University, Durham, UK

$9 \quad{ }^{3}$ City of Phoenix Water Services Department, Phoenix AZ USA

${ }^{4}$ Corresponding author 


\section{ABSTRACT}

Constructed treatment wetlands have been well established as effective and sustainable solutions to the problem of urban water treatment and reuse. However, treatment wetlands located in aridland cities may behave differently relative to their more mesic and humid counterparts, and this could potentially impact their ability to deliver the ecosystem services that are expected of them. Specifically, in hot, dry climates large water losses via evaporation and plant transpiration may comprise a major component of whole-system water budgets. Our primary goal was to develop a rigorous and informed model of how well these "working wetlands" function in hot, arid climates by developing and comparing robust water and nutrient budgets, as our process-based understanding of how mesic constructed wetlands function may not be readily transferred to arid climates where constructed wetlands are becoming increasingly widespread. At the Tres Rios constructed treatment wetland in Phoenix AZ USA, we quantified water losses via plant transpiration and open water evaporation as well as inorganic $\mathrm{N}$ loads into and from the whole wetland system and into the vegetated marsh. We found that water losses due to transpiration and evaporation were remarkably high when compared to most mesic constructed wetlands. Total water losses via evaporation and transpiration peaked at $300,000 \mathrm{~m}^{3}$ $\mathrm{mo}^{-1}\left(714 \mathrm{~L} \mathrm{H}_{2} \mathrm{O} \mathrm{m}^{-2} \mathrm{mo}^{-1}\right)$ in the hot, dry summer months and averaged more than $70 \%$ of the whole-system water losses over a 27 month time period. At the same time, the vegetated marsh removed nearly all of the inorganic $\mathrm{N}$ that was supplied to it. Large transpirative water losses moved large volumes of replacement water into the marsh via a "biological tide" that provided more opportunities for vegetation and soil microbes to process $\mathrm{N}$ and other target solutes. This enhanced the $\mathrm{N}$ treatment efficacy of the Tres Rios constructed treatment wetland relative to humid, mesic systems. To our knowledge, this is the first time that biotically-mediated surface hydrology has been demonstrated in any wetland.

Keywords: Constructed treatment wetlands, water budgets, nutrient budgets, nitrogen removal, transpiration, urban wetlands 


\section{INTRODUCTION}

The last two centuries have been characterized by a dramatic shift in human demographics and land use practices, with more people choosing cities and urban areas as their primary habitat. Specifically, since 1900 the human population living in urban areas has increased from $10 \%$ to over $50 \%$ globally, with that proportion projected to grow to $80 \%$ by 2050 (Grimm et al. 2008). As urban centers grow in size and number, so do their demands for resources and services. In particular, the last century has seen the transformation of many cities into "sanitary cities", with highly centralized, capitalized, and expensive infrastructure designed to keep inhabitants healthy (Melosi 2000; per Grove 2009). This development of infrastructure has imparted considerable inertias on cities that make it more difficult for decision-makers to envision, let alone implement, novel or transformative new solutions to growing problems (Childers et al. 2014). Still, there are a number of ways in which urban infrastructure may make cities more resilient and sustainable by designing to optimize key ecosystem services (Pickett et al. 2013). One example of using infrastructure to optimize key ecosystem services is the increasing use of constructed treatment wetlands as part of wastewater treatment plants in place of expensive and energy-intensive treatment technologies.

Constructed treatment wetlands are a relatively low cost and low maintenance solution to the age-old problem of wastewater treatment and, more recently, water reclamation. They are especially attractive due to the fact that variable wastewater pathways and often relatively remote placement of wastewater treatment systems demand simple technologies that require little active management (Wallace and Knight 2006; Nivala et al. 2013). Most treatment wetlands are characterized by the presence of macrophytic vegetation, waterlogged or saturated soils, and municipal effluent that must be treated (Fonder and Headley 2013). While these wetlands share similar ecosystem service expectations, or "jobs", of removing nutrients or other solutes (Tanner et al. 2012), they may be further differentiated with regards to the level of "hard" engineering components designed into them. These range from totally passive (horizontal flow) systems to intensely managed systems featuring pulse loading or active aeration (Fonder and Headley 2010). Design choices for treatment wetlands are often highly dependent on local or regional variables, including imposed statutory wastewater treatment regulations or site-specific conditions. Importantly, basic differences, such as climate, may limit general conclusions that might be drawn from comparative studies of treatment wetland efficacy (Nivala et al. 2013). While 
treatment wetlands are relatively similar in design and expectations, particular attention must be

74 paid to the way these systems function in their respective climatic settings.

In arid environments, which occupy more than $30 \%$ of the earth's land surface, one of the

76 biggest challenges facing cities is the scarcity of water. As a result, many of these cities are

77 increasingly turning to the reuse of treated municipal effluent as a means of reclaiming and recycling water for various urban uses (Greenway 2005). Notably, in the aridland city of Phoenix AZ USA, virtually all municipal effluent is reused within the city (Metson et al. 2012), and the only significant export of water from the city is via evaporative losses to the atmosphere. The challenge facing water reuse is that using reclaimed water in densely populated areas requires that this water be clean. Increasingly, water service providers are turning to treatment wetlands that, in addition to cleaning effluent, can also provide auxiliary and serendipitous ecosystem services such as habitat for birds and other fauna and recreational spaces for urban dwellers. However, constructed treatment wetlands in hot, arid cities may face unique challenges relative to similar systems in more mesic and humid settings. In particular, treatment wetlands in hot, dry climates should lose large amounts of water to evaporation and plant transpiration. How aridland treatment wetlands perform under these conditions is not well quantified nor well understood, and our primary goal for this research was to better understand these dynamics. To address this goal, we quantified water and nutrient budgets for a constructed treatment wetland in Phoenix.

In Phoenix, annual precipitation averages $180 \mathrm{~mm}$ while potential wetland evapotranspiration is over $2100 \mathrm{~mm}$ (Kadlec 2008). Thus, the objectives driving our research in this wetland were: 1) to use a nutrient budget approach to determine net inorganic nitrogen $(\mathrm{N})$ removal by the vegetated marsh and the whole system; 2) to measure transpirational water losses from the emergent macrophytes; 3) to calculate a dynamic water budget for the system based on surface water inflows and outflows, precipitation inputs, and estimates for open-water evaporation and plant transpiration, and; 4) to determine how well this aridland wetland removed $\mathrm{N}$ from municipal wastewater effluent.

Historically, phase-change atmospheric losses of water from wetlands have been

101 understand $\mathrm{E}_{\mathrm{t}}$ in wetlands have been confounded by large differences in estimates across 102 wetlands as well as divergences in the many ways that $\mathrm{E}_{\mathrm{t}}$ may be calculated (Goulden et al. 103 2007). For the purposes of our study, we conceptually and empirically separated plant-mediated 
104 transpirational water losses from open-water evaporation. Transpirational water losses have been

105 reported as both larger and smaller than water losses due to open-water evaporation, but it seems

106 probable that transpiration dominates water loss in wetlands found in hot, arid climates

107 (Pauliukonis and Schneider 2001). In fact, this has been documented for a wetland near our study

108 system (Kadlec 2006). Open-water evaporation should also be high in these systems, and there

109 are a variety of approaches to this calculation (Kumar et al. 2012). Many approaches to

110 estimating $\mathrm{E}_{\mathrm{t}}$ in wetlands have calculated it as a residual term in whole-system water and energy

111 budgets that are based on meteorological data. However, a fundamental limitation with this

112 approach for our study was that this "subtraction" approach did not articulate spatial

113 heterogeneity and site-specific nuances that affect $\mathrm{E}_{\mathrm{t}}$, such as water level, plant community

114 composition, and plant canopy structure (Lott and Hunt 2001).

115 The objectives we addressed in this study are clearly not new to the constructed treatment

116 wetland literature. However, researchers have seldom rigorously studied wetlands that are

117 specifically designed to perform particular ecosystem services but are located in hot, arid

118 climates. Our research sought to tease apart the key components of the wetland water budget and

119 combine them with a nutrient budget in order to understand how well the constructed treatment

120 wetland we studied was performing. Our ultimate goal was to arrive at a more informed model of

121 aridland wetland ecosystem service performance that can facilitate the best possible adaptive

122 management of these systems.

123

\section{2. METHODS}

125 2.1. Site Description

126 Our study was conducted at the constructed treatment wetland associated with the $91^{\text {st }}$

127 Avenue Wastewater Treatment Plant, which is the largest such facility in Phoenix. Construction

128 of the 3-cell Tres Rios wetland system was completed in 2009-2010 and we began our work

129 there in Summer 2011. We have focused our work on the largest of three wetland cells, which

130 was planted first and came online in Summer 2010 (Figure 1). Each wetland cell is bounded by

131 levee roads, and the cell we studied is 42 ha in size, half of which is fringing vegetated marsh

132 and half of which is mostly open water with several small upland "islands". Water depths in the

133 marsh were consistently about $25 \mathrm{~cm}$ while open water depths were 1.5 to $2 \mathrm{~m}$; because of the

134 way water was managed in the system, these depths did not vary. Our study cell received from 
13595,000 to over $270,000 \mathrm{~m}^{3} \mathrm{~d}^{-1}$ of effluent, depending on the time of year. The marsh areas were 136 planted with seven emergent wetland species that are native to Arizona: Typha latifolia, Typha

137 domingensis, Schoenoplectus acutus, Schoenoplectus americanus, Schoenoplectus californicus,

138 Schoenoplectus maritimus, and Schoenoplectus tabernaemontani. Schoenoplectus maritimus was

139 a minor component of the plant community and was out-competed within the first year of our

140 research (Weller et al. this issue), so we focused our transpiration measurements only on the

141 other six species.

142

\subsection{Transpiration Measurements and Evaporation Calculations}

144 We utilized a dual-gradient experimental design to study the two major hydrologic

145 pathways of the wetland system: A whole-system gradient from the inflow to the outflow, and a

146 within-marsh gradient that included 10 transects from the shore to the open water that were

147 distributed evenly along the whole system gradient (Figure 1; for details, see Weller et al. this

148 issue). All of our sampling followed a bimonthly schedule (January, March, May, July,

149 September, and November), and we present data from July 2011 through September 2013 in this

150 paper. We measured leaf-specific gas flux along marsh transects that included all species groups

151 using a LICOR LI-6400 handheld infrared gas analyzer (IRGA). Measurements were made on

152 individual T. latifolia, T. domingensis, S. acutus, S. americanus, S. californicus, and S.

153 tabernaemontani plants at 50-cm intervals from near the water surface to the top of the canopy.

154 We collected gas flux data continuously from early morning until as late in the day as was

155 feasible. For logistical reasons, we sampled one transect at a time, with individual plants chosen

156 haphazardly until all species present in that transect had been sampled a number of times. Due to

157 site access restrictions, we were unable to collect nighttime transpiration data and thus assumed

158 that nighttime transpirative water loss was negligible. Notably, this assumption is one reason that 159 our transpiration estimates are conservative.

160 Several of the Schoenoplectus species have thick stems which required us to modify the

161 stock LI-6400 IRGA sampling chamber in order to get a gas-tight seal without crushing the plant

162 stems. To remedy this, we used custom-made foam pads that allowed us to seal the leaf chamber

163 around these stems while minimizing damage to the plant material. Specifically, we were

164 interested in IRGA measurements of leaf-specific transpiration rate $\left(\mathrm{Tr} ; \mathrm{mmol} \mathrm{H}_{2} \mathrm{O} \mathrm{m}^{-2} \mathrm{sec}^{-1}\right)$,

165 photosynthetically active radiation (PAR, $\mu$ mol photons), ambient air temperature $\left({ }^{\circ} \mathrm{C}\right)$, and 
relative humidity (\%). All of these measurements were taken using the IRGA's default internal sensors. Daily transpiration data were expressed in units of leaf surface area, and we converted surface area to dry weight biomass by drying and weighing 8-10 samples of different surface areas and generating relationships between surface area and dry weight biomass for each species $\left(\mathrm{r}^{2}>0.90\right.$ and $\mathrm{p}<0.01$ in all cases $)$.

Half of the 42 ha wetland cell we sampled was open water, as determined by digitizing and measuring aerial imagery in ArcGIS (ver 10.0, ESRI, Redlands, CA). We calculated openwater evaporation (E, in $\mathrm{mm} \mathrm{hr}^{-1}$ ) using the Shuttleworth (1993) variation of the Penman (1948) equation:

Open Water Evaporation $=((\mathrm{S} * \mathrm{PAR})+\mathrm{C} * 6.43 *(1+0.536 * \mathrm{~V}) * \mathrm{VPD}) /(2.39 *(\mathrm{~S} * \mathrm{C}))$ using hourly data for air temperature $(\mathrm{T})$, relative humidity $(\mathrm{RH})$, irradiance (PAR), barometric pressure (P), vapor pressure deficit (VPD), slope of the saturation vapor pressure curve (S), psychrometric constant (C), and wind speed (V) logged at an on-site meteorological station operated by the City of Phoenix (hereafter referred to as the "meteorological station"). If the hourly meteorological station data were missing or not reliable for any necessary variable $(<5 \%$ of all hourly readings), we did not calculate transpiration or open-water evaporation. Because of these missing data, we are confident that our evaporation water loss values are underestimates and are further confident that our transpiration estimates are conservative. Finally, we calculated internal water loss using a dynamic monthly water budget for the whole system by summing the whole-system hourly water fluxes via open water evaporation (E) and plant transpiration (Tr) to monthly totals:

$$
\text { Internal Water Loss }=\mathrm{E}+\mathrm{Tr}
$$

and compared these data with the monthly whole-system water deficit, which we calculated by summing daily inflows $\left(\mathrm{SW}_{\mathrm{i}}\right)$, rainfall $(\mathrm{R})$, and outflows $\left(\mathrm{SW}_{\mathrm{o}}\right)$ for the month and subtracting the latter from the former:

$$
\text { Water Budget Deficit }=\mathrm{SW}_{\mathrm{i}}+\mathrm{R}-\mathrm{SW}_{\mathrm{o}}
$$

$\mathrm{SW}_{\mathrm{i}}, \mathrm{SW}_{\mathrm{o}}$, and $\mathrm{R}$ measurements were taken from whole-system data sets provided by the City of Phoenix (see Section 2.4 for details). After consultation with on-site engineers, we determined that vertical losses via percolation to groundwater were negligible so this parameter was not included in our water budget deficit calculations. 


\subsection{Water Quality Sampling}

On the same bimonthly schedule described above, we collected water quality samples along both gradients. Triplicate water samples were collected by hand in acid-washed Nalgene bottles at the inflow and outflow points of the study cell, and at the shore and open-water ends of three marsh transects that represented the inflow-outflow whole system gradient (Figure 1). Nitrate $\left(\mathrm{NO}_{3}{ }^{-}\right)$, nitrite $\left(\mathrm{NO}_{2}{ }^{-}\right)$, and ammonium $\left(\mathrm{NH}_{4}{ }^{+}\right)$samples were centrifuged to remove particulates and analyzed on a Lachat Quick Chem 8000 Flow Injection Analyzer (detection limit $0.85 \mu \mathrm{g} \mathrm{NO}_{3}-\mathrm{N} / \mathrm{L}$ and $3.01 \mu \mathrm{g} \mathrm{NH} \mathrm{NH}_{4} \mathrm{~N} / \mathrm{L}$ ). For simplicity, we will restrict our water quality analysis to dissolved inorganic nitrogen $\left(\mathrm{NH}_{4}{ }^{+}, \mathrm{NO}_{3}{ }^{-}\right.$, and $\left.\mathrm{NO}_{2}{ }^{-}\right)$. Differences in water quality data were determined using a paired t-test for whole-system inflow versus outflow data, while an unequal variance t-test was used for shore versus open water marsh transect data.

\subsection{Whole System Data}

Our research at the Tres Rios constructed treatment wetland is in partnership with the City of Phoenix Water Services Department, and they provided us with key whole system datasets for our analyses. We used their daily inflow $\left(\mathrm{SW}_{\mathrm{i}}\right)$ and outflow $\left(\mathrm{SW}_{\mathrm{o}}\right)$ data (in $\mathrm{mgd}$, converted to $\mathrm{m}^{3} \mathrm{~d}^{-1}$ ), measured using standard acoustic Doppler flow meters, to calculate total monthly water flux into and out of our study cell from January 2012 through September 2013. For the months when we sampled the system, we combined total monthly water flux with inorganic $\mathrm{N}$ concentrations to calculate whole system monthly $\mathrm{N}$ loads. We used the previously discussed hourly meteorological station data to scale our transpiration estimates in time and to calculate evaporative water losses from the open-water component of our study cell (see Sections 2.2 and 2.5 for details). Because of inconsistencies in the rainfall data collected by the on-site meteorological station, we summed daily rainfall data from the nearby Goodyear airport to calculate monthly rainfall contributions $(\mathrm{R})$ to the whole system water budget.

\subsection{Data-Scaling and Water Budget Calculations}

An important step in our whole-system water budget estimates was the scaling of leafspecific measurements of transpiration water losses from individual plants to 21 ha of marsh, and from transpiration measurements made over the course of individual days to a $2+$ year timeseries. To scale transpiration water flux across space (Daily $\operatorname{Tr}_{\text {System }} ; \mathrm{m}^{3} \mathrm{H}_{2} \mathrm{O} \mathrm{d}^{-1}$ whole system ${ }^{-1}$ ), 
227 we combined our IRGA measurements (Instantaneous $\operatorname{Tr}_{\text {IRGA; }}$ mmol $\mathrm{H}_{2} \mathrm{O} \mathrm{m}^{-2} \mathrm{sec}^{-1}$ ), corrected for 228 dry-weight plant biomass (Area/Bio; $\mathrm{cm}^{2} \mathrm{gdw}^{-1}$ ), with the whole system live macrophyte 229 biomass $\left(\right.$ Bio $_{\text {System }}$; $\mathrm{Mg}$ whole system ${ }^{-1}$ ) calculated from the bimonthly data collected along our 23010 marsh transects (see Weller et al. this issue):

$$
\text { Daily } \operatorname{Tr}_{\text {System }}=\text { Instantaneous } \operatorname{Tr}_{\text {IRGA }} * \text { Area/Bio } * \text { Bio }_{\text {System }} * 74.06
$$

232 where 74.06 was a dimensional analysis conversion for $\mathrm{mmol} \mathrm{H}_{2} \mathrm{O}$ to $\mathrm{m}^{3} \mathrm{H}_{2} \mathrm{O}$, seconds to days, 233 and gdw biomass to $\mathrm{Mg}$ biomass for the 21 ha marsh. To estimate whole system biomass

234 (Bio System $)$ we developed phenometric models that allowed us to non-destructively estimate live 235 biomass for all plant species by making simple allometric measurements in the field (per Daoust 236 and Childers 1998; Childers et al. 2006). Every two months, we measured all of the plants in 237 five $0.25 \mathrm{~m}^{2}$ quadrats that were randomly located along each of the 10 marsh transects shown in 238 Figure 1, for a total of $500.25 \mathrm{~m}^{2}$ quadrats sampled (for details Weller et al. this issue). We used 239 simple linear interpolation to extrapolate plant biomass between bimonthly samplings, producing 240 daily estimates of live macrophyte biomass from July 2011 through September 2013.

241 To scale our plant-specific transpirational water losses in time, we used the

242 micrometeorological data generated by the IRGA at the time of sampling and the corresponding 243 hourly data from the on-site meteorological station. Because plant transpiration flux is driven 244 largely by T, PAR, and RH (Sánchez-Carrillo et al. 2001), we first regressed hourly 245 meteorological station data for these three variables against the mean of all IRGA measurements 246 for the same variables for that same hour for each transpiration sampling day. We then generated 247 multiple regression models that related transpiration flux for each macrophyte species (per $\mathrm{Mg}$ 248 dry weight of plant biomass) to PAR, T, and RH as measured by the IRGA. These models 249 combined with the IRGA-meteorological station regressions allowed us to use continuous data 250 from the meteorological station to interpolate our species-specific transpiration measurements 251 through time, resulting in whole-system daily transpirative losses (in $\mathrm{m}^{3} \mathrm{H}_{2} \mathrm{O}$ day ${ }^{-1}$ for the 21 ha 252 of vegetated marsh) from July 2011 through September 2013. See Table 1 for a summary of all 253 parameters, applications, methods, and sampling frequencies used to for these calculations. 


\section{RESULTS AND DISCUSSION}

\subsection{Transpiration}

The phenometric biomass models were the same for T. latifolia and T. domingensis, and for S. acutus and S. tabernaemontani (see Weller et al. this issue for details). For this reason we combined our leaf-specific transpiration measurements for both species of each genus in both cases. Transpiration rates for S. californicus and S. americanus were treated separately and discretely. On a typical hot, dry day in July, these rates were as high as 10,14, 13, and $9 \mathrm{mmol}$ $\mathrm{H}_{2} \mathrm{O} \mathrm{m}^{-2}$ leaf area s $\mathrm{s}^{-1}$ for Typha spp., S. acutus + S. tabernaemontani, S. californicus, and $S$. americanus, respectively. In January, when air temperatures were low and plant biomass was at its annual minimum, the highest transpiration rates were only 2, 4, 4, and $6 \mathrm{mmol} \mathrm{H}_{2} \mathrm{O} \mathrm{m}^{-2}$ leaf area $\mathrm{s}^{-1}$ for Typha spp., S. acutus + S. tabernaemontani, S. californicus, and S. americanus, respectively. These rates equated to July 2011 averages of $30 \pm 0.8,16 \pm 0.4,0.6 \pm 0.3$, and $9.6 \pm$ $0.02 \mathrm{~mm}$ day $^{-1}$ and January 2014 averages of $1.7 \pm 0.2,1 \pm 0.03,0.4 \pm 0.03$, and $0.4 \pm 0.03 \mathrm{~mm}$ day $^{-1}$ for the entire standing stock of Typha spp., S. acutus + S. tabernaemontani, S. californicus, and S. americanus, respectively. By comparison, Pedescoll et al. (2013) found that a $T$. angustifolia-dominated constructed wetland in a similarly arid climate transpired a maximum of $23 \mathrm{~mm}$ day $^{-1}$, which is similar to the maximum rates from our treatment wetland. In contrast,

273 individual T. domingensis plants in the humid, mesic Florida Everglades transpired up to 11 mmol m${ }^{-2} \sec ^{-1}$ (Koch and Rawlik 1993) — well below the maximum plant-specific rates we measured for this species. Reported transpiration rates for Typha spp. are even lower in cooler climates: $5.8 \pm 0.9 \mathrm{~mm} \mathrm{day}^{-1}$ in marshes along Oneida Lake NY USA (Pauliukonis and Schneider 2001) and $6.5 \mathrm{~mm} \mathrm{day}^{-1}$ in marshes in Ohio, USA (Martin et al. 2003). These findings illustrate the dramatic differences in transpiration water loss between hot, arid and cooler, mesic wetlands.

We scaled these leaf-specific IRGA gas flux measurements in time to generate estimates of daily water loss by plant transpiration for the entire 21 ha vegetated marsh using hourly data from the on-site meteorological station. Regression relationships between meteorological station data and measurements within the canopy allowed us to extrapolate transpiration measurements between our bimonthly samplings. Multivariate regressions relating transpiration rate to T, RH, and PAR found that only T and PAR were significant predictors of transpiration by all four plant species groups, with relatively little interspecies variation in the strength of the relationships $\left(r^{2}=\right.$ 
0.57 to 0.67 ; all p-values $<0.01)$. We scaled leaf-specific transpiration measurements in space

288 using the live macrophyte biomass estimates for each species group from Weller et al. (this issue) after converting transpiration rates from $\mathrm{mmol} \mathrm{H}_{2} \mathrm{O} \mathrm{m}^{-2}$ leaf area s${ }^{-1}$ to $\mathrm{ml}_{2} \mathrm{O}$ gdw biomass ${ }^{-1}$ day $^{-1}$ and ultimately to $\mathrm{m}^{3} \mathrm{H}_{2} \mathrm{O}$ day ${ }^{-1}$ for the entire 21 ha marsh. We found considerable variation in transpirative water losses among the four species groups, with Typha spp. having the largest average transpiration rate $\left(2614 \pm 58 \mathrm{~m}^{3} \mathrm{H}_{2} \mathrm{O}\right.$ day ${ }^{-1}$ or $12.45 \pm 0.28 \mathrm{~L} \mathrm{H}_{2} \mathrm{O}$ $\mathrm{m}^{-2}$ day $\left.^{-1}\right)$ and $S$. californicus the lowest average rate $\left(221 \pm 5 \mathrm{~m}^{3} \mathrm{H}_{2} \mathrm{O}\right.$ day ${ }^{-1}$ or $1.05 \pm 0.02 \mathrm{~L}$ $\mathrm{H}_{2} \mathrm{O} \mathrm{m}^{-2}$ day $\left.^{-1}\right)$. Most, but not all, of this variation was driven by differences in the amount of live biomass (Weller et al. this issue). In fact, although Typha spp. has been steadily taking over the macrophyte community in our study wetland (Weller et al. this issue), S. acutus and S. tabernaemontani continued to make a contribution to overall daily transpirative water losses that was disproportionate to their contributions to total biomass (Figure 2). This disproportionate contribution to daily transpirative water loss was likely due to the fact that these large-stemmed bulrushes transpire considerably more water per unit biomass than do cattails.

As expected, all species groups showed strong seasonality, with the highest transpirational water losses in the hot, dry summer months and the lowest losses in the winter months (Figures 2 and 3). While close relationships between transpiration and seasonal variation in climate and biomass have been well documented in the literature (e.g. Moro et al. 2004; Pedescoll et al. 2013), the rates of water transpired from our Tres Rios system were considerably higher than even those from other arid wetlands. For example, Drexler et al. (2008) found that an arid wetland in California, USA transpired on average $6 \mathrm{~mm} \mathrm{day}^{-1}$, and Goulden et al. (2007) reported peak annual transpiration of less than $5 \mathrm{~mm} \mathrm{day}^{-1}$ for another marsh in California. A study conducted by Bialowiec et al. (2014) in a cooler, more mesic wetland in Poland reported a maximum system-wide transpiration rate of $4.6 \mathrm{~mm} \mathrm{~d}^{-1}$, and Abtew (1996) found that Typhadominated marsh systems in the warm, humid Florida Everglades had maximum transpirational losses of only $3.6 \mathrm{~mm} \mathrm{day}^{-1}$. Overall, Tres Rios had transpirative water losses that were as much as an order of magnitude greater than has been reported for other wastewater treatment wetlands. Whole-system macrophyte biomass exhibited regular seasonality, with peak biomass in July of approximately 400 to $600 \mathrm{Mg}$ for the 21 ha marsh (Figure 3). As expected, whole-system transpiration losses closely mirrored plant biomass (Figure 3). The highest total monthly 
318 transpiration losses of approximately 200,000 to $300,000 \mathrm{~m}^{3}$ for the 21 ha marsh were in June

319 and July, when ambient air temperatures regularly exceeded $45^{\circ} \mathrm{C}$ and relative humidity was

320 typically below $10 \%$, and often below 5\%. As we noted above, during this study, the plant

321 community was tending towards a bi-specific stand of T. domingensis and T. latifolia, but the

322 contribution of several Schoenoplectus species to transpiration flux remained strong (Figure 2).

\subsection{Whole System Water Budget}

325 Daily inflow and outflow data for our wetland study cell were used to calculate wholesystem monthly water deficits. The inflow sensor was not fully operational until January 2012, and therefore whole-system water deficit was not calculated until January 2012 (Figure 4). The whole-system water budget was dominated by transpirational water losses and open water evaporation, the latter of which represented a lower fraction of our total water budget - on the order of a third or less - during the hotter months when plant biomass was higher and the plants were most productive (Figure 4). Notably, precipitation was only a small fraction of the water budget. During our study, Tres Rios received $105 \mathrm{~mm}\left(105 \mathrm{~L} \mathrm{H}_{2} \mathrm{O} \mathrm{m}^{-2} \mathrm{yr}^{-1}\right.$ or 44,100 m $\mathrm{yr}^{-1}$ ), $122 \mathrm{~mm}\left(122 \mathrm{~L} \mathrm{H}_{2} \mathrm{O} \mathrm{m} \mathrm{yr}^{-1}\right.$ or $\left.51,240 \mathrm{~m}^{3} \mathrm{yr}^{-1}\right)$, and $167 \mathrm{~mm}\left(167 \mathrm{~L} \mathrm{H}_{2} \mathrm{O} \mathrm{m}^{-2} \mathrm{yr}^{-1}\right.$ or $70,140 \mathrm{~m}^{3}$ $\mathrm{yr}^{-1}$ ) of rainfall annually in 2011, 2012, and 2013 respectively. These inputs were very small when compared with transpiration and evaporation losses of $2.5-3.0$ million $\mathrm{m}^{3} \mathrm{y}^{-1}$. In 2012 and 2013, precipitation comprised on average $0.8 \%$ (with a maximum of $4.1 \%$ in January 2013) of the whole system monthly water deficit, while from 2011 to 2013 precipitation comprised on average only $1.9 \%$ (with a maximum of $16.2 \%$ in December 2012) of the total water losses via transpiration and open water evaporation.

In many months our transpiration + evaporation-based water budget was remarkably

343 transpiration + evaporation represented an average of $70 \%$ of the whole-system water deficit

344 throughout the study period (67\% if March-May 2012 are included; see Figure 4 legend for

345 explanation). This consistency lends confidence in our scaled-up transpiration measurements and

346 calculations of open water evaporation. Notably, these contributions of evaporation and

347 transpiration are much higher than those reported for constructed wetlands in mesic, humid 348 climates. For example, Meuleman et al. (2003) reported that transpiration and evaporation 
comprised only $13 \%$ of the water budget for a constructed wetland in the Netherlands, where the

350 climate is considerably cooler, more humid, and wetter than in Phoenix. Similarly, Kadlec et al.

351 (2010) reported that transpiration and evaporation represented only $3 \%$ of total water outputs for

352 a treatment wetland in Columbia, Missouri, USA and Favero et al. (2007) reported that these two

353 water losses comprised only about $10 \%$ of the water budget for a constructed wetland near

354 Venice, Italy.

\subsection{Water Quality and Nitrogen Budget}

We focused our analysis of nutrient sequestration on nitrogen $(\mathrm{N})$, specifically dissolved inorganic nitrogen $\left(\mathrm{NO}_{3}{ }^{-}\right.$and $\left.\mathrm{NH}_{4}{ }^{+}\right)$, because this was the focus of the City's Clean Water Act permit for the treatment wetland. At the whole-system scale, inflow loads of both $\mathrm{NO}_{3}{ }^{-}$and $\mathrm{NH}_{4}{ }^{+}$ were nearly always higher than outflow loads (Figure 6a and 6b), with inflow loads averaging $532 \pm 84(\mathrm{SE}) \mathrm{kg} \mathrm{d}^{-1}$ and $169 \pm 19(\mathrm{SE}) \mathrm{kg} \mathrm{N} \mathrm{d}^{-1}$ and outflow loads averaging $417 \pm 67(\mathrm{SE}) \mathrm{kg} \mathrm{N}$ $\mathrm{d}^{-1}$ and $87 \pm 17(\mathrm{SE}) \mathrm{kg} \mathrm{d}^{-1}$ for $\mathrm{NO}_{3}{ }^{-}$and $\mathrm{NH}_{4}{ }^{+}$, respectively. The monthly whole-system $\mathrm{N}$ uptake rates averaged $3.51 \pm 0.98(\mathrm{SE})\left(16.71 \pm 4.66 \mathrm{~g} \mathrm{~N} \mathrm{~m}^{-2} \mathrm{mo}^{-1}\right)$ and $2.48 \pm 0.61(\mathrm{SE})(11.81$ $\left.\pm 2.90 \mathrm{~g} \mathrm{~N} \mathrm{~m}^{-2} \mathrm{mo}^{-1}\right) \mathrm{Mg} \mathrm{N} \mathrm{mo}^{-1}$ for $\mathrm{NO}_{3}{ }^{-}$and $\mathrm{NH}_{4}{ }^{+}$, respectively, from July 2011 through September 2013. On average, $22 \%$ of nitrate inputs and $48 \%$ of ammonium inputs were taken up between the whole-system inflow and outflow in spite of the short water residence time of the system and the likelihood that much of this water did not come into physical contact with the vegetated marsh that makes up $50 \%$ of the system by area.

Within the vegetated marsh, we were able to compare $\mathrm{N}$ concentrations along the three marsh transects but did not have water flux data to calculate actual nutrient removal rates. Still,

372 we consistently found much lower concentrations of dissolved inorganic $\mathrm{N}$ in the near-shore

373 water overlying the marsh, compared with concentrations at the marsh-open water interface. This 374 pattern was most dramatic for $\mathrm{NO}_{3}{ }^{-}$, with near-shore concentrations that were often at or below 375 the detection limit (Figure 6a). Marsh removal of $\mathrm{NH}_{4}{ }^{+}$was also consistent through time and across seasons, but was less dramatic than with $\mathrm{NO}_{3}{ }^{-}$(Figure 6b). Weller et al. (this issue) estimated $\mathrm{N}$ uptake rates by the plants themselves based on productivity and tissue stoichiometry and found that $19 \%$ of the whole-system $\mathrm{N}$ removal could be directly accounted for by plant 
uptake. Even without actual nutrient flux estimates, it seems clear that the vegetated marsh was active and efficient in $\mathrm{N}$ removal, regardless of time of year.

\subsection{A Plant-Mediated "Biological Tide"}

The $\mathrm{N}$ concentration data from along our marsh transects (Figure 6) suggested that whole-system efficiency might easily be improved if more $\mathrm{N}$-rich water could directly interact with the vegetated marsh. One possible mechanism for this is the lateral movement of water into the marsh to replace losses via plant transpiration, particularly in the summer when the plants are most productive, soil temperatures are highest, and transpiration is maximal. This lateral movement of water into the vegetated marsh is what we are calling a plant-mediated "biological tide." We refer to it as a "tide" because it is an active horizontal advection from open water areas into the vegetated marsh that is analogous to astronomical tides seen in coastal wetlands. To our knowledge, this is the first time that such control of surface hydrology by plants has been documented in a wetland.

We investigated this "biological tide" by calculating the volume of water overlying the marsh that was lost daily to transpiration. Water depth measurements at the 50 transect points where aboveground plant biomass was measured showed that water depth was consistent across space and time, with a mean of $24 \mathrm{~cm}$. We subtracted the portion of this water volume that was occupied by plant stems by scaling up stem culm diameter measurements, and used this corrected volume to estimate transpirational losses. During the summer months, as much as $15-$ $20 \%$ (approximately 8,000 to $11,000 \mathrm{~m}^{3} \mathrm{H}_{2} \mathrm{O}$ day $^{-1}$ ) of the total volume of water overlying the marsh was transpired daily and must have been replaced by a lateral flow from the open-water areas to maintain the observed constant water depths (Figure 7). These values are conservative estimates because we were not able to account for the volume of water occupied by extensive thatched dead vegetation (i.e., wrack) on the marsh surface, thus suggesting that summertime

These transpirative losses from the vegetated marsh, and lateral flow to replace them, 407 were thus substantial. We argue that this plant-driven control of wetland hydrology, or 408 "biological tide", may be an important mechanism in arid systems to move additional nutrients water residence times in the marsh were likely less than 4-5 days. 
410 nutrients both laterally into the marsh and vertically down into the soils, creating more

411 opportunities for plants to take up $\mathrm{N}$ and for soil microbes to process $\mathrm{N}$ and other bioactive

412 solutes as Martin et al. (2003) and others have suggested. In fact, we argue that this "biological

413 tide" phenomenon makes the Tres Rios treatment wetland more efficient at nutrient removal, and

414 thus more effective at providing desired ecosystem services, than its counterparts in more mesic,

415 humid climates. This phenomenon may actually be at work in many other treatment wetlands

416 located in hot, dry climates. However, the high volume of water loss that drives the "biological

417 tide" means that there is a trade-off between the provision of water-cleansing ecosystem services

418 and the volume of water with improved water quality that can be exported from these systems for 419 local reuse.

\subsection{Summary}

422 We found that water losses due to transpiration and evaporation were remarkably high 423 compared with constructed wetlands in more humid, mesic climates. Total water losses via both 424 processes peaked at over $300,000 \mathrm{~m}^{3} \mathrm{month}^{-1}$ in the hot, dry summer months and averaged more 425 than $70 \%$ of the whole-system water losses from June 2011 through September 2013. We found 426 that large transpirative water losses actually appeared to enhance $\mathrm{N}$ removal efficacy relative to 427 humid, mesic systems by drawing large volumes of replacement water and solutes into the marsh 428 via a "biological tide". This plant-mediated "tide" appears to be replacing more than $20 \%$ of the 429 total volume of water overlying the marsh during hot, dry summer months. Transpiration-driven 430 movement of shallow subsurface water has been documented in a number of wetlands, including 431 into tree islands in the Okavango Delta in Botswana (Bauer-Gottwein et al. 2007, Ramberg and 432 Wolski 2008) and in the Florida Everglades (Bazante et al. 2006, Troxler-Gann and Childers 433 2006, Sullivan et al. 2012). But, to our knowledge, this is the first time that biotically-mediated 434 surface hydrology has been demonstrated in any wetland. 
436 The first year of this work was supported by the U.S. Geological Survey through a grant 437 from the Arizona Water Resources Research Institute. Additional support was provided by the 438 National Science Foundation through the Urban Sustainability Research Coordination Network 439 (Grant No. 1140070) and the Central Arizona-Phoenix Long-Term Ecological Research Program 440 (Grant No. 1027188). We thank Ben Warner for his contributions early in the project, Cathy 441 Kochert for lab assistance with nutrient analyses, the City of Phoenix Water Services Department 442 for their support and for providing access to Tres Rios and key datasets, Dakota Tallman for 443 coordinating much of the research conducted in 2013, and many student volunteers who helped 444 with the field and laboratory work. 
Abtew W., 1996. Evapotranspiration measurements and modeling for three wetland systems in South Florida. Journal of the American Water Resources Association. 32(3):465-473.

Bauer-Gottwein, P., T. Langer, H. Prommer, P. Wolski, and W Kinzelbach, 2007. Okavango Delta Islands: interaction between density-driven flow and geochemical reactions under evapo-concentration. Jour. Hydrology 335:389-405.

Bazante, J., G. Jacobi, H. Solo-Gabriele, D. Reed, S. Mitchell-Bruker, D.L. Childers, L. Leonard, and M. Ross, 2006. Hydrologic measurements and implications for tree island formation within Everglades National Park. J. Hydrology 329:606-619.

Bialowiec A., Alburquerque A., Randerson O.F., 2014. The influence of evapotranspiration on vertical flow subsurface constructed wetland performance. Ecological Engineering. 67:89-94.

Childers, D.L., Iwaniec D., Rondeau D., Rubio G., Verdon E., and Madden C., 2006. Primary productivity in Everglades marshes demonstrates the sensitivity of oligotrophic ecosystems to environmental drivers. Hydrobiologia. 569(1):273-292.

Childers, D.L., Pickett S.T.A., Grove J.M., Ogden L., Whitmer A., 2014. Advancing urban sustainability theory and action: Challenges and opportunities. Landscape \& Urban Planning. 125:320-328.

Daoust, R., Childers D.L., 1998. Quantifying aboveground biomass and estimating productivity in nine Everglades wetland macrophytes using a non-destructive allometric approach. Aquatic Botany. 62:115-133.

Drexler J.Z., Anderson F.E., Snyder R.L., 2008. Evapotranspiration rates and crop coefficients for a restored marsh in the Sacramento-San Joaquin Delta, California, USA. Hydrological Processes. 22:725-735.

Favero, L., Mattiuzzo E., and Franco D., 2007. Practical results of a water budget estimation for a constructed wetland. Wetlands 27(2):230-239.

Fonder N., Headley T., 2010. Systematic classification, nomenclature, and reporting for constructed treatment wetlands. In: Vymazal J (Ed.). Water and Nutrient Management in Natural and Constructed Wetlands. Springer Science + Business Media B.V., Dordrect. 191-219.

Fonder N., Headley T., 2013. The taxonomy of treatment wetlands: A proposed classification and nomenclature system. Ecological Engineering. 51:203-211.

Goulden M.L., Litvak M., Miller S.D., 2007. Factors that control Typha marsh evapotranspiration. Aquatic Botany. 86:97-106. 
Grimm N.B., Faeth S.H., Golubiewski N.E., Redman C.L., Wu J., Bai X., Briggs J.M., 2008. Global Change and the Ecology of Cities. Science. 319:756-760.

Greenway M., 2005. The role of constructed wetlands in secondary effluent treatment and water reuse in subtropical and arid Australia. Ecological Engineering. 25:501-509.

Grove, J. M., 2009. Cities: Managing densely settled social-ecological systems. Pp. 281-294 in F. S. Chapin III, G. P. Kofinas, and C. Folke, eds., Principles of Ecosystem Stewardship: Resilience-Based Natural Resource Management in a Changing World. Springer. New York, NY.

Kadlec R.H., 2006. Water temperature and evapotranspiration in surface flow wetlands in hot arid climate. Ecological Engineering. 26:328-340.

Kadlec R.H., 2008. The effects of wetland vegetation and morphology on nitrogen processing. Ecological Engineering. 33:126-141.

Kadlec R.H., Cuvellier C., Stober T., 2010. Performance of the Columbia, Missouri, treatment wetland. Ecological Engineering. 36:672-684.

Koch M.S., Rawlik P.S., 1993. Transpiration and Stomatal Conuctance of Two Wetland Macrophytes (Cladium jamaicense and Typha domingensis) in the Subtropical Everglades. American Journal of Botany. 80(10):1146-1154.

Kumar R., Jat M.K., Shankar V., 2012. Methods to estimate irrigated reference crop evapotranspiration - a review. Water Science and Technology. 66(3):525-535.

Lott R.B., Hunt R.J., 2001. Estimating evapotranspiration in natural and constructed wetlands. Wetlands. 21(4):614-628.

Martin J., Hofherr E., Quigley M.F., 2003. Effects of typha latifolia transpiration and harvesting on nitrate concentrations in surface water of wetland microcosms. Wetlands. 23(4):835844.

Melosi M.V., 2000. The Sanitary City: Environmental Services in Urban America from Colonial Times to the Present. Johns Hopkins University Press. Baltimore MD.

Metson, G., Hale R., Iwaniec D., Cook E., Corman J., Galletti C., Childers D., 2012. Phosphorus in Phoenix: A budget and spatial representation of phosphorus in an urban ecoystem. Ecolological Applications. 22(2):705-721.

Meuleman A.F.M., Logtestijn R. van, Rijs G.B.J., Verhoeven J.T.A., 2003. Water and mass budgets of a vertical-flow constructed wetland used for wastewater treatment. Ecological Engineering. 20:31-44. 
Moro M.J., Domingo F., López G., 2004. Seasonal transpiration pattern of Phragmites australis in a wetland of semi-arid Spain. Hydrological Processes. 18: 213-227.

Nivala J., Headley T., Wallace S., Bernhard K., Brix H., Afferden M. van, Müller R.A., 2013. Comparative analysis of constructed wetlands: The design and construction of the ecotechnology research facility in Langenreichenbach, Germany. Ecological Engineering. 61:527-543.

Pauliukonis N., Schneider R., 2001. Temporal patterns in evapotranspiration from lysimeters with three common wetland plant species in the eastern United States. Aquatic Botany. 71:35-46.

Pedescoll A., Sidrach-Cardona R., Sánchez J.C., Bécares E., 2013. Evapotranspiration affecting redox conditions in horizontal constructed wetlands under Mediterranean climate: Influence of plant species. Ecological Engineering. 58:335-343.

Penman, H.L., 1948. Natural evaporation from open water, bare soil and grass. Proceedungs of the Royal Society of London Series A, Mathematical and Physical Sciences. 193(1032):120-145.

Pickett, S.T.A., Boone C.G., McGrath B.P., Cadenasso M.L., Childers D.L., Ogden L.A., McHale M., and Grove J.M., 2013. Ecological science and transformation to the sustainable city. Cities. 32:S10-S20.

Ramberg, L., and P. Wolski, 2008. Growing islands and sinking solutes: processes maintaining the endorheic Okavango Delta as a freshwater system. Plant Ecology 196:215-231.

Sánchez-Carrillo S., Álvarez-Cobelas M., Benítex M., 2001. A simple method for estimating water loss by transpiration in wetlands. Hydrological Sciences. 46(4):537-552.

Shuttleworth WJ. 1993. Evaporation. Chapter 4. In Handbook of Hydrology, Maidment DR. McGraw-Hill: New York, USA.

Sullivan, P., R.M. Price, F. Miralles-Wilhelm, M.S. Ross, L.J. Scinto, T.W. Dreschel, F.H. Sklar, E. Cline. 2012. The role of recharge and evapotranspiration as hydraulic drivers of ion concentrations in shallow ground water on Everglades tree islands, Florida (USA). Hydrological Processes DOI: 10.1002/hyp.9575.

Tanner C.C., Sukias J.P.S., Headley T.R., Yates C.R., Stott R., 2012. Constructed wetalnds and denitrifying bioreactors on-site and decentralized waterwater treatment:comparison of five alternative configurations. Ecological Engineering. 42:112-123.

Troxler-Gann, T. and D.L. Childers, 2006. Relationships between hydrology and soils describe vegetation patterns in tree seasonally flooded tree islands of the southern Everglades, Florida. Plant \& Soil 279:271-286. 
577 Wallace S.D., Knight R.L., 2006. Small-Scale Constructed Wetland Treatment Systems:

$578 \quad$ Feasibility, Design Criteria, and O\&M Requirements. Water Environment Research Foundation (WERF). Alexandria, VA. wetlands I: Macrophyte productivity, community composition, and nitrogen uptake. Ecol. Engineering (this issue). 
587 Figure 1: The Tres Rios constructed treatment wetland cell used in this study. Blue arrows show the effluent inflow and outflow points and white lines are the approximate locations of the 10 marsh transects (each 50-60 m long). Water quality samples were collected at the inflow and outflow points and at 1) the northernmost transect closest to the inflow, 2) the

Figure 2: Total daily water loss via plant transpiration from the 21 ha of vegetated marsh. TYPHA=Typha domingensis and T.latifolia; SAC/STAB=Schoenoplectus acutus and $S$. tabernaemontani; $\mathrm{SAM}=S$. americanus, and; $\mathrm{SCAL}=S$. californicus. southernmost transect nearest to the outflow, and the 3) eastern transect in between them. Total cell area $=42$ ha; 21 ha of vegetated marsh and 21 ha of open water.

Figure 5: Whole system nitrate (A) and ammonium (B) flux into the study cell (circles) and out of the study cell (squares).

613 Figure 7: Estimates of the volume of water overlying the 21 ha of vegetated marsh that was transpired daily by the plants and had to be replaced by the "biological tide". 
616 Figure 8: Conceptual schematic of our hypothesized "biological tide" in which high rates of plant 617 transpiration, particularly during the hot, dry summer months, drive a lateral movement 618 of water and solutes into the marsh and vertically down into marsh soils from the open619 water areas. This biotically-mediated water flow may be replacing the entire volume of 620 water overlying the marsh every $4-5$ days at peak transpiration rates. 
623 Figure 1:

624

625

626

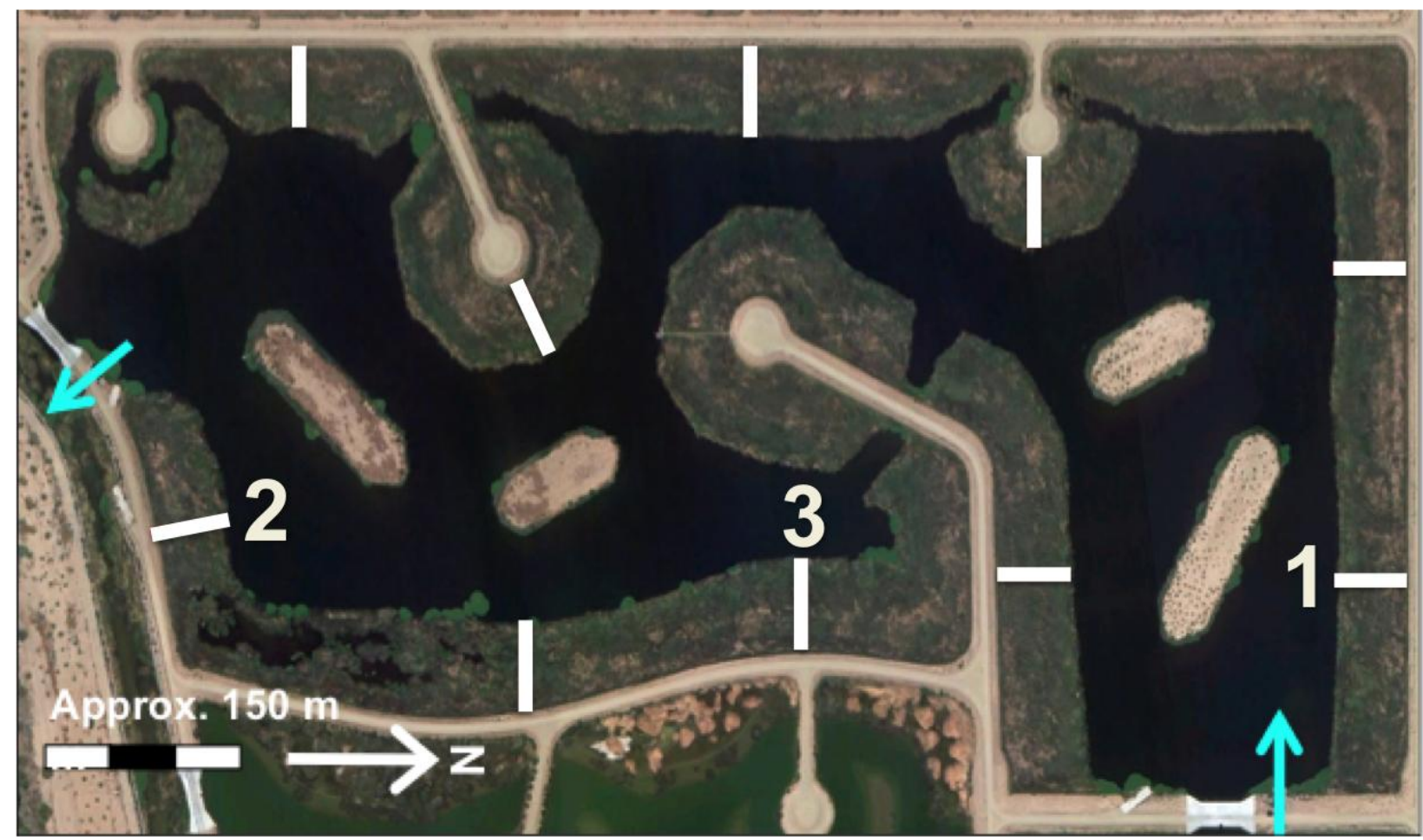

627 
628

629

630

631

632

633
Figure 2:

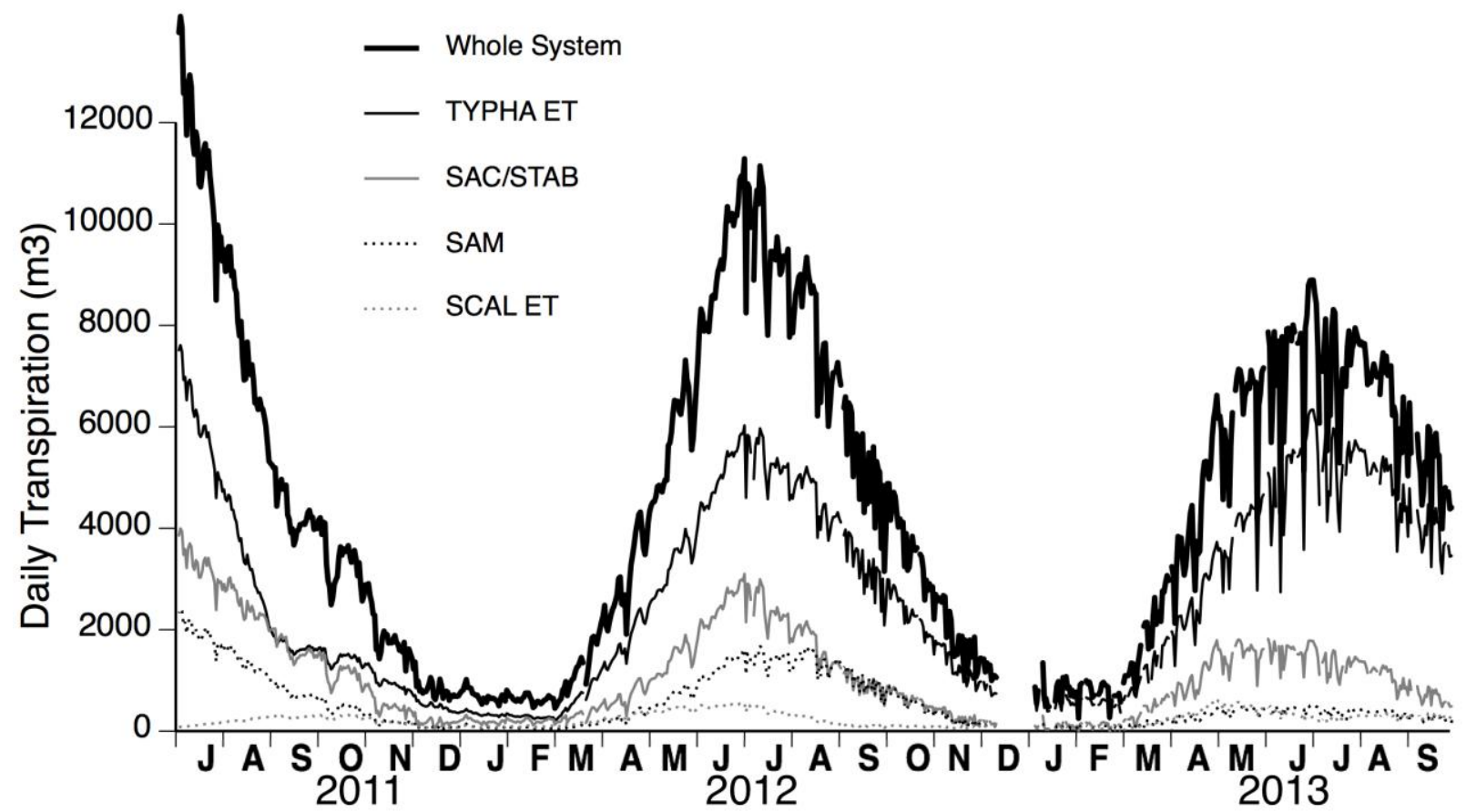


634 Figure 3:

635

636

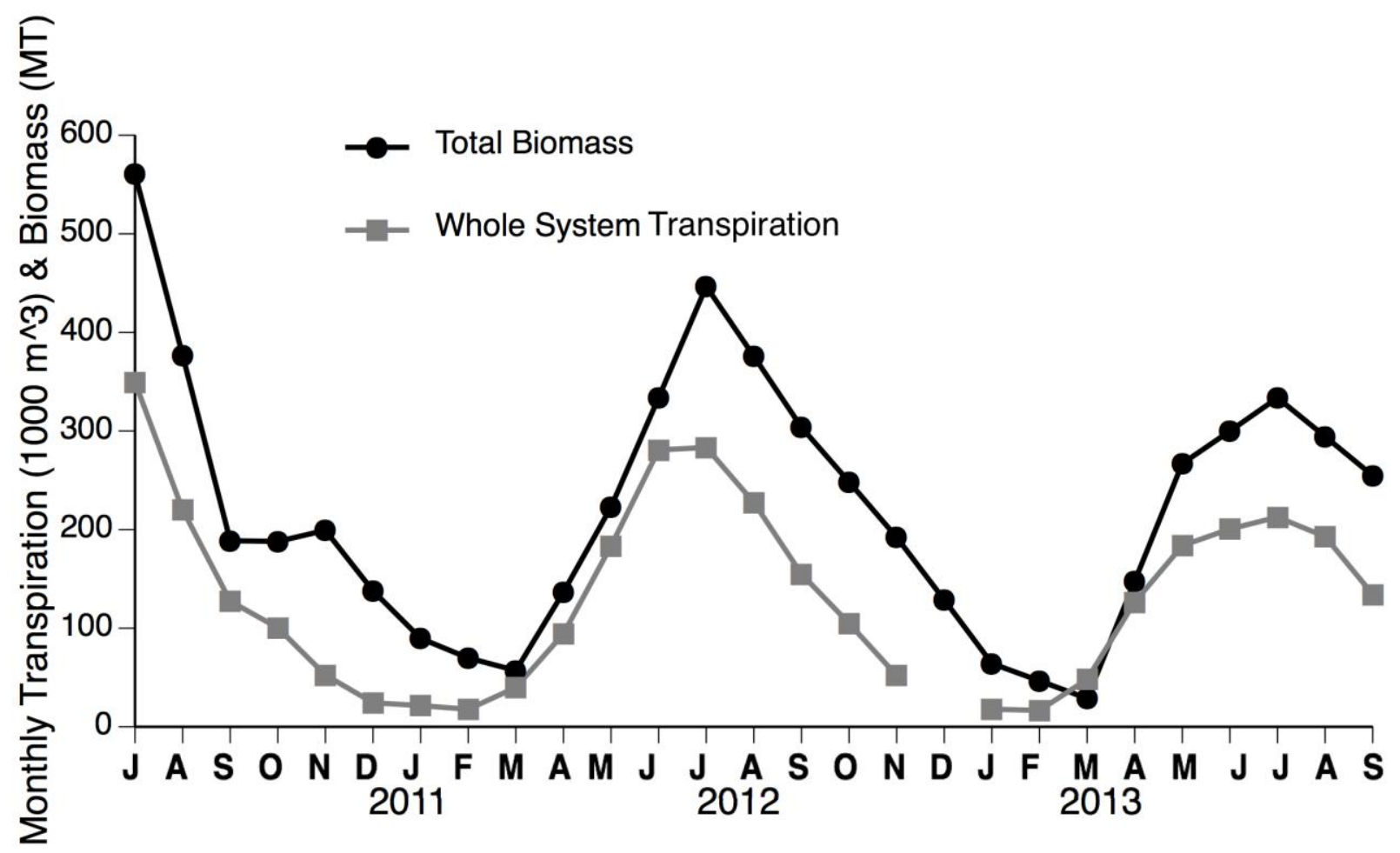

637

638 
639

640

641

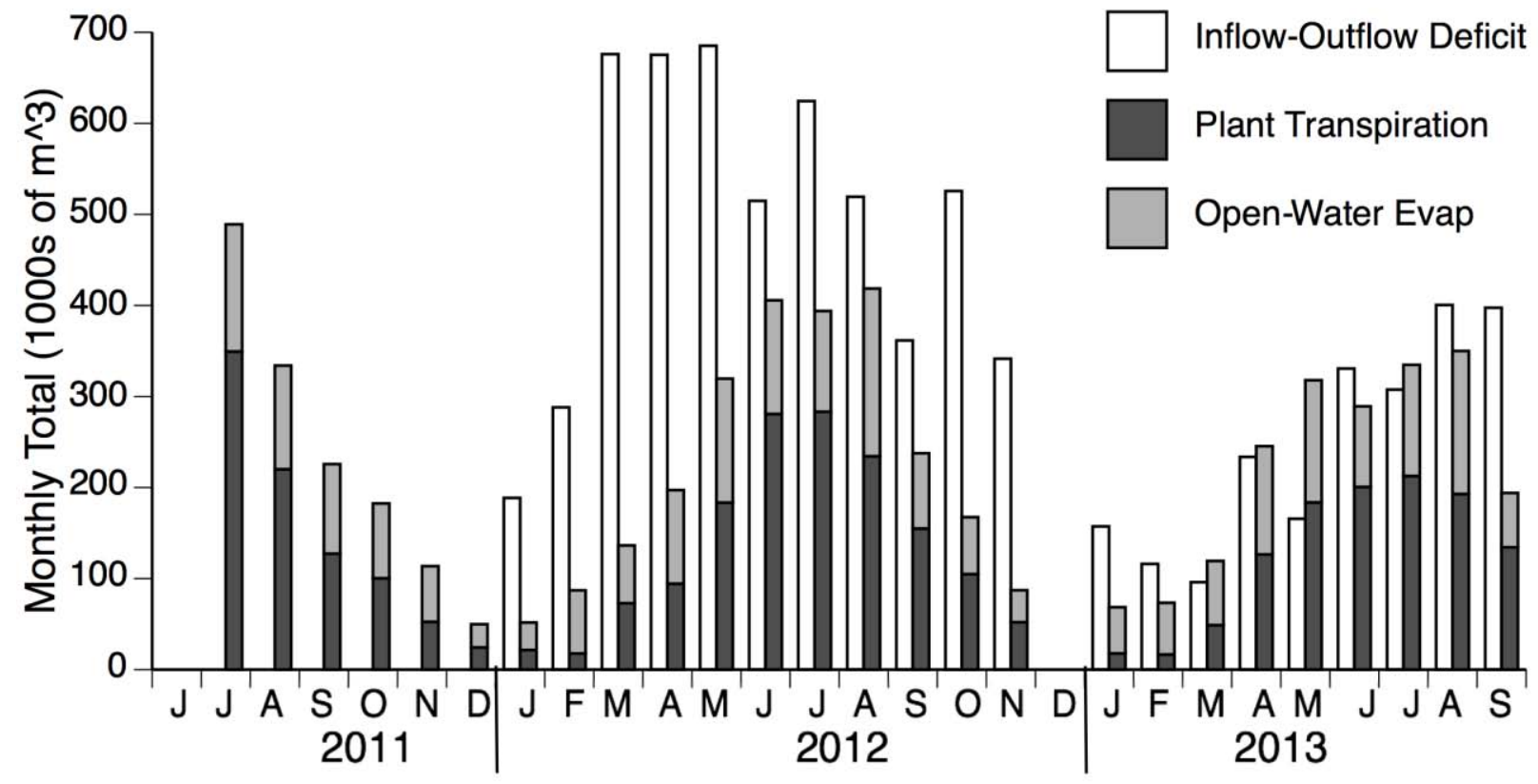

642

Figure 4:

643 
644 Figure 5:

645
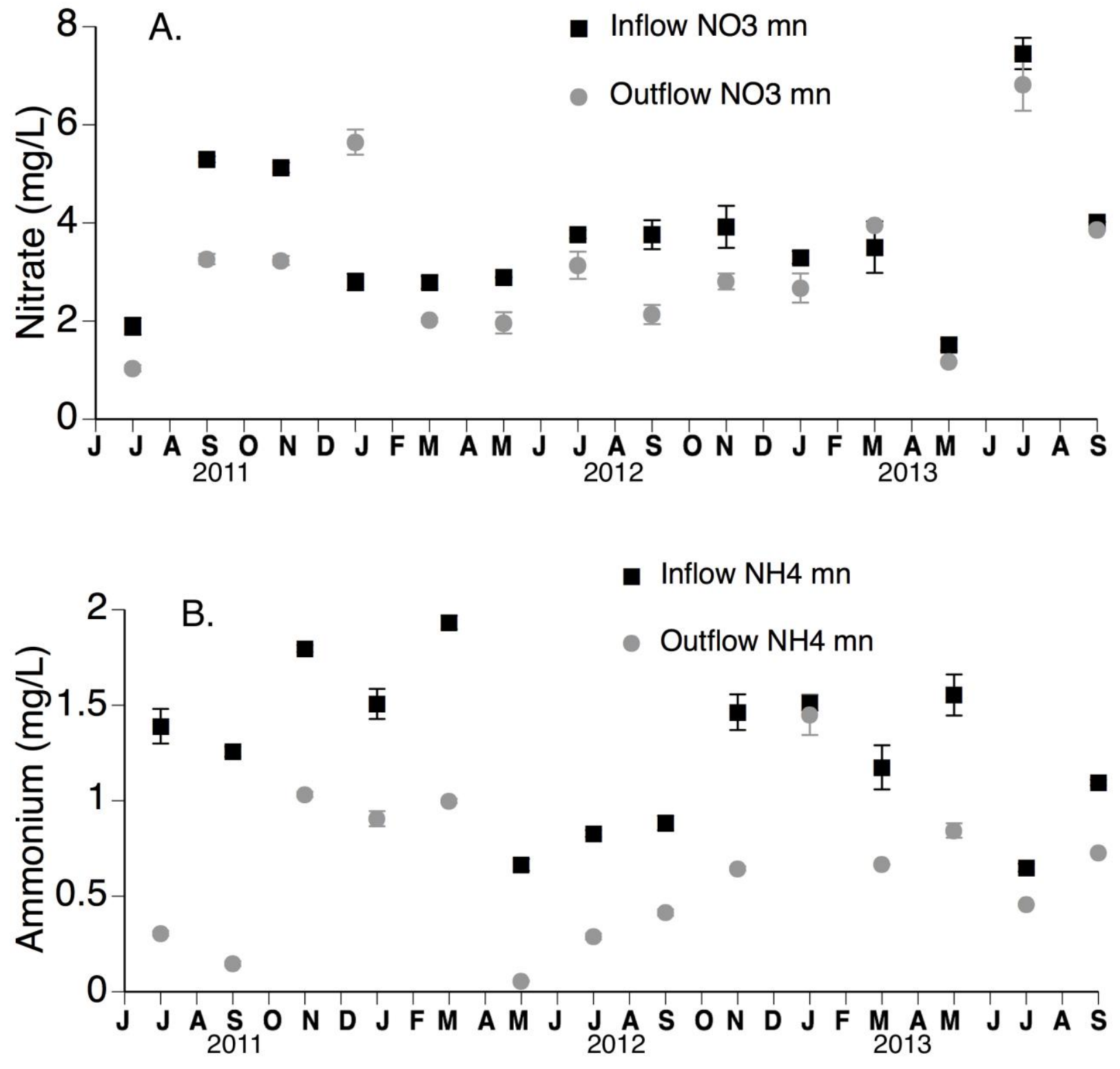
652 Figure 6:

653

654

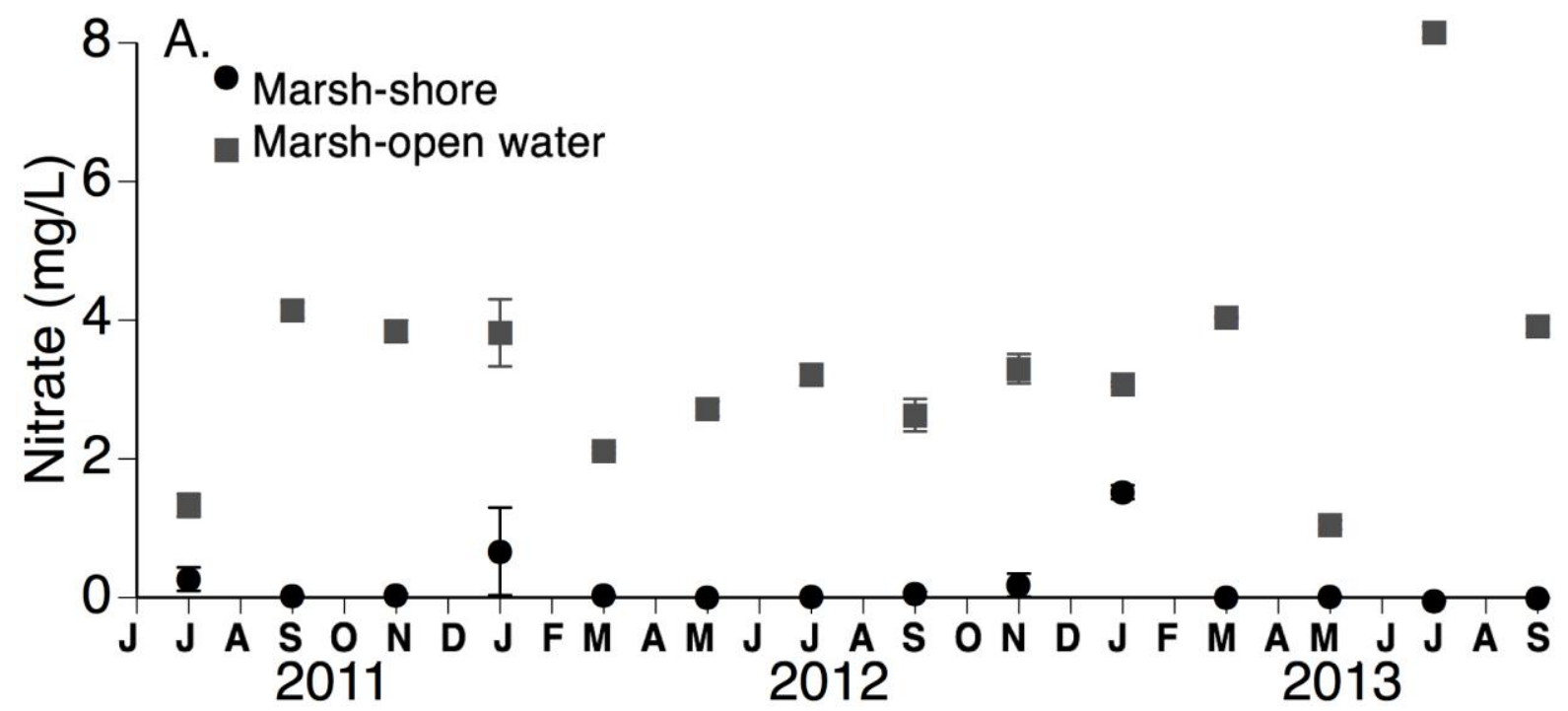

655

656

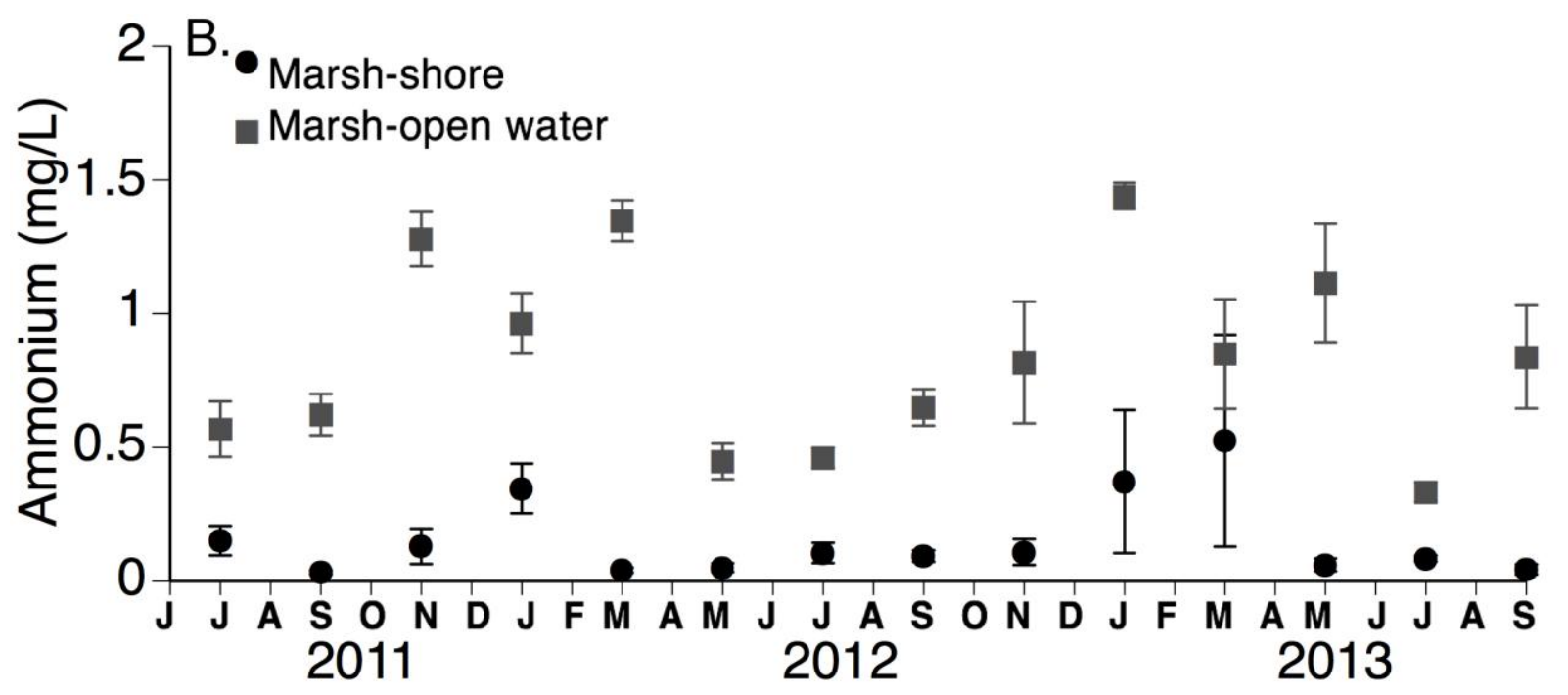

658

659

660 
661 Figure 7:

662

663

664

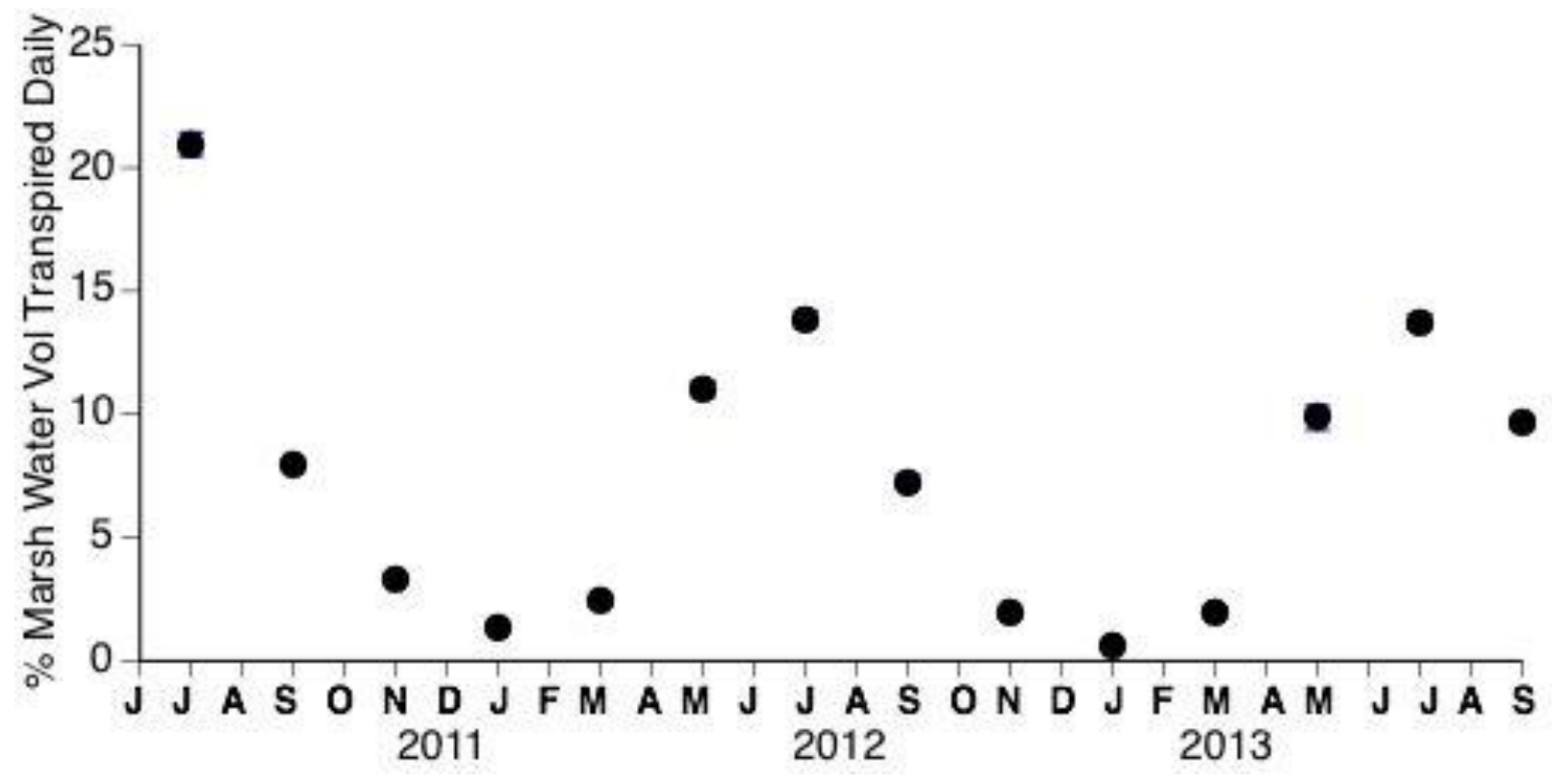

665 
666 Figure 8:

667

668

669

670

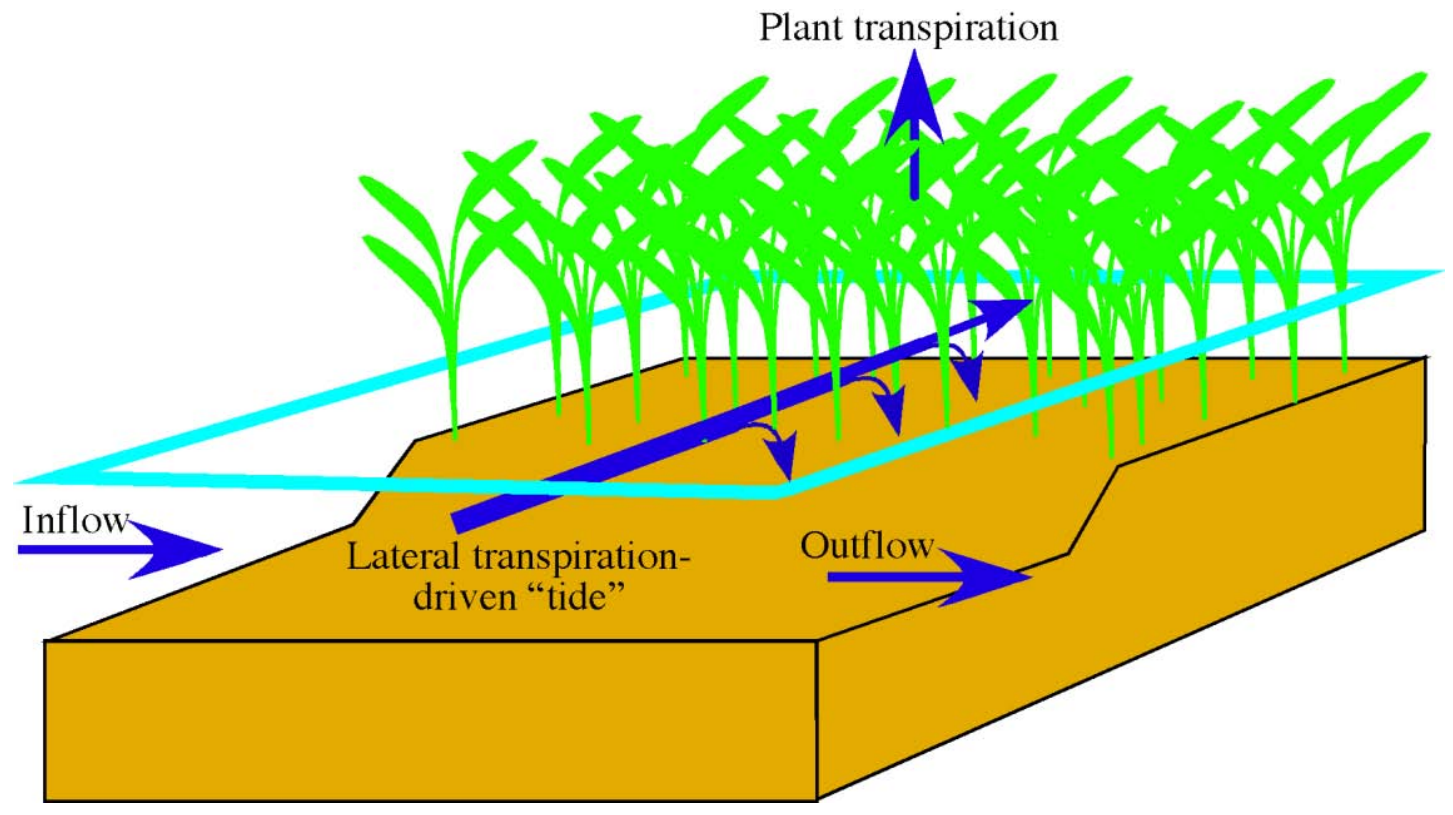


672 Table 1: Summary of the parameters, applications, methods, and sampling frequencies for all

673 variables used to estimate whole-system plant transpiration, open water evaporation, and 674 water budgets.

675 


\section{TABLES}

Table 1:

\begin{tabular}{|l|l|l|}
\hline \multicolumn{1}{|c|}{ Parameter and Application } & \multicolumn{1}{c|}{ Methods } & \multicolumn{1}{c|}{ Data Frequency } \\
\hline $\begin{array}{l}\text { Transpiration, leaf area, leaf-level } \\
\text { RH, leaf-level PAR, leaf-level T; } \\
\text { used to estimate whole system } \\
\text { plant transpiration }\end{array}$ & Infrared Gas Analyzer (IRGA) & Bi-monthly \\
\hline $\begin{array}{l}\text { Ambient RH, ambient PAR, } \\
\text { ambient T, wind speed, vapor } \\
\text { pressure deficit, R; used to } \\
\text { calculate open water evaporation } \\
\text { and to scale plant transpiration in } \\
\text { time }\end{array}$ & $\begin{array}{l}\text { On-site meteorological station } \\
\text { (City of Phoenix) }\end{array}$ & Hourly \\
\hline $\begin{array}{l}\text { Surface water inflow, surface water } \\
\text { outflow; used to calculate water } \\
\text { budget deficit }\end{array}$ & $\begin{array}{l}\text { Acoustic Doppler flow gauges } \\
\text { (City of Phoenix) }\end{array}$ & Daily \\
\hline $\begin{array}{l}\text { Aboveground plant biomass for } 4 \\
\text { species groups; used to scale plant } \\
\text { transpiration in space }\end{array}$ & $\begin{array}{l}\text { Non-destructive phenometric } \\
\text { technique (Weller et al. this } \\
\text { issue) }\end{array}$ & Bi-monthly \\
\hline
\end{tabular}

